\title{
Parenting Style Influencing Emotions and Attitudes Among Gifted and Talented Students
}

\author{
Effa Rinny Octavia Paidin ${ }^{1}$, Abu Yazid Abu Bakar ${ }^{2 *}$, Kadek Suranata ${ }^{3}$ \\ ${ }^{1,2}$ Universiti Kebangsaan Malaysia, ${ }^{3}$ Universitas Pendidikan Ganesha \\ *Corresponding author, e-mail: yazid3338@ukm.edu.my
}

Received August 02, 2021; Revised August 31, 2021; Accepted Sept. 20, 2021; Published Online 2021-10-01

\section{Conflict of Interest} Disclosures:

The authors declare that they have no significant competing financial, professional or personal interests that might have influenced the performance or presentation of the work described in this manuscript.

\begin{abstract}
The development of emotional intelligence is formed as a result of various aspects and one of them is through social interaction among the family. This study aims to see the trend or parenting style that can influence attitudes and emotions among clever students. The focus of this study is to identify the emotional problems and attitudes of clever students, as well as to identify parenting styles that affect the emotions and attitudes of clever students. This study was carried out following the hypothesis that there was no correlation between the emotional problems of the clever students and parenting style, and there is no correlation between the problems of the attitude of the clever students with the parenting style. This is a cross-sectional study, using a nonstandard questionnaire built by the researcher, which researchers obtained information on parenting styles that influenced emotions and attitudes among clever students in three high-performance schools in Kuching, Sarawak. The population of the study involved 60 students of various levels from three outstanding academic achievers in Kuching, Sarawak, randomly selected. The implications from this study, parents will be able to see and explore every one of the parenting styles that will affect the emotions and attitudes of children, thus improving themselves in giving the best love for children.
\end{abstract}

Keywords: Attitudes, emotions, gifted and talented students, parenting styles

\section{Introduction}

Adolescent development is influenced by its environment. According to Zuria, Razak and Salleh (2001), the closest and most important environment for adolescents is the family. This is because the family is the most basic institution in the formation of the attitudes and personality of adolescents. Likewise the academic achievement of students depends not only on how the learning process in the classroom is carried out, but also depends on how the individual personality process is formed, and the applied familial aspects affect the individual himself (Amy, 2000). 
The family is a social institution that plays a very important role in shaping the emotions, attitudes and moral behaviors of students. Mustafa (1997) explains that the construction and formation of the ummah starts from the family institution. All religious teachings demand towards good and reject all evil. The main basis should be emphasized from an early age is the level of socialization of children through religious aspects, as the Malay proverb says 'let the bamboo bend from the shoot'.

According to Rosmah (2004), the family institution is the first school for a child in shaping life with parents, the family is also the first teacher. A baby begins to learn from seeing and then imitates the behavior and speech of those around him. As Zulkifli (2007) said, parents are the best role models for children. Kimberly (2007) states that going through adolescence is often described as the most critical and challenging moments for an adolescent as well as a parent. Effective parental education must take into account all the needs of all aspects of adolescent development so that the process of adjustment that adolescents go through can be passed as well as possible.

The family plays an important role in the development of an individual, in terms of emotions, attitudes and behavior. Parents are the main pillars that shape adolescents, as parents are the first individuals involved in the process of socialization and development of children (Hamidah, 2013; Goleman, 1995; Bowlby, 1982). Throughout adolescent growth and development, it is heavily influenced by parents through parent-child relationships (Salimynezhad, Poor, \& Valizade, 2015). The failure of parents in fulfilling every aspect of children's development, will have a great impact on the children themselves. The development of adolescent emotional intelligence should be flexed from an early age to form a group of adolescents with high emotional intelligence. Thus parents are the main pillars, as parents are the first individuals involved in the process of socialization and development of children (Hamidah, 2013; Goleman, 1995; Bowlby, 1982).

There is an assumption that this group of gifted students rarely face problems related to emotions and attitudes. But the fact is, these gifted students are also no exception to face the same situation as other students. Therefore, there are some parents who often cause stress to their children, especially in terms of improvement and commitment at the most excellent level from the academic aspect. This condition sometimes causes stress on the psyche of children, and in turn can lead to negative attitudes and behaviors to channel feelings of stress from parents.

Loeber and Farrington (2000) and Loeber and Stouthamer-Loeber (1986) found that parenting style practices are important in shaping children's development. Noorzihan (2004) states that children's morals start from home. Children from an early age and most of the time are in the family circle. Thus, every personality, mental, physical, emotional and attitudinal development of children is under the control of the parents in particular, and the institution of the family in general. The effectiveness of parents in performing their roles depends on their interaction and communication with children.

Every parent wants their children to be good human beings in all respects, but parents should first show good character and example for children to follow. In this day and age, teenagers are exposed to an environment that can bring teenagers to a negative scene, if teenagers are brought up in a lame upbringing environment at home. Without the maturity of mind adequately supplied by the parents to the children, it will open up space for the children themselves to be stuck with unhealthy symptoms on the outside.

Past studies have been conducted on the relationship between parenting styles that affect students' attitudes, personalities and behavioral problems. Yet researchers overlooked related issues of the same, but were also faced by gifted students, where they also faced emotional and attitude problems that were influenced by parenting style. In this study, researchers will study about parenting styles that influence emotions and attitudes among gifted and talented students, in three high schools in Kuching area.

\section{Method}

\section{Research Design}

This study is descriptive, which is a survey by questionnaire in which it aims to get an idea of something that is happening. According to Azizi et al. (2006), a descriptive survey aims to obtain measurements or descriptions related to the conditions or characteristics of the population. In this study, researchers wanted to obtain information on parenting styles that influence emotions and attitudes among gifted and talented students, in three high -performing schools in Kuching, Sarawak. 


\section{Research Subjects}

The study population involved 60 students of various levels from three secondary schools with outstanding academic performance in Kuching, Sarawak, who were randomly selected. In general, researchers use any subject or sample available for most studies or research conducted (Mohd Majid, 1993). Three schools with excellent academic performance have been selected around Kuching, Sarawak. Each school, there will be 20 respondents randomly selected from various levels. Three schools that achieved the best academic performance in the area around the city of Kuching, Sarawak were selected as the place for this study. Schools with outstanding academic performance were selected to conduct this study because this study was to look at parenting styles that influence emotions and attitudes among gifted and talented students.

\section{Research Instruments}

This study involves the distribution of questionnaires because this method is easier to administer by the school and the data obtained is easy to analyze. The distribution of questionnaires in this study aims to obtain feedback on the research questions and information required. From the respondents. The research instrument is in the form of a non -standard questionnaire constructed by the researcher. The questionnaire submitted to the respondents is divided into 3 parts, namely parts $\mathrm{A}, \mathrm{B}$, and C. Part A will look at the most dominant emotional problems among intelligent students. Part B will look at the most dominant attitude problems among intelligent students. Section $C$ will look at parenting styles that influence the emotions and attitudes of intelligent students.

\section{Results and Discussion}

The questionnaire was distributed to 60 respondents, consisting of 38 female respondents and 22 male respondents. To all responses were randomly selected from various levels, and from the three best academically performing schools in Kuching. Part A looked at the most dominant emotional problems among intelligent students: $51.7 \%$ said they felt depressed, $48.3 \%$ sometimes felt like crying for no apparent reason, $98.3 \%$ wanted themselves valued, and $98.3 \%$ also wanted themselves given trust.

Table 01. Emotional Problems Among Gifted and Talented Students

\begin{tabular}{|c|c|c|c|}
\hline No & Items & Yes & No \\
\hline 1 & I feel depressed & $51.7 \%$ & $48.3 \%$ \\
\hline 2 & I'm not confident & $50 \%$ & $50 \%$ \\
\hline 3 & I did not dare to make a decision & $43.3 \%$ & $56.7 \%$ \\
\hline 4 & I'm worried about hanging out/making friends with other people & $25 \%$ & $75 \%$ \\
\hline 5 & I was hesitant to manage myself & $20 \%$ & $80 \%$ \\
\hline 6 & I sometimes cry for no apparent reason & $48.3 \%$ & $51.7 \%$ \\
\hline 7 & I am not happy with my life & $28.3 \%$ & $71.7 \%$ \\
\hline 8 & I always felt like I had failed & $28.3 \%$ & $71.7 \%$ \\
\hline 9 & I want myself to be valued & $98.3 \%$ & $1.7 \%$ \\
\hline 10 & I want myself to be trusted & $98.3 \%$ & $1.7 \%$ \\
\hline
\end{tabular}

Section B looked at the most dominant attitude problems among intelligent students: $68.3 \%$ who felt like screaming with all their might, $48.3 \%$ who felt like punching something or someone, $48.3 \%$ who felt like doing something out of the norm, $61.7 \%$ who felt their life boring, $66.7 \%$ who feel angry or upset suddenly, and $100 \%$ say they don't like it when their privacy is violated. 
Table 02. Attitude Problems Among Gifted and Talented Students

\begin{tabular}{clcc}
\hline No & \multicolumn{1}{c}{ Items } & Yes & No \\
\hline 1 & I sometimes feel like screaming & $68.3 \%$ & $31.7 \%$ \\
2 & I sometimes feel like skipping class/school & $43.3 \%$ & $56.7 \%$ \\
3 & I sometimes feel like punching something/someone & $48.3 \%$ & $51.7 \%$ \\
4 & I sometimes feel like hurting myself & $31.7 \%$ & $68.3 \%$ \\
5 & I sometimes feel like doing something out of the norm & $48.3 \%$ & $51.7 \%$ \\
6 & I sometimes feel my life is boring & $61.7 \%$ & $38.3 \%$ \\
7 & I sometimes suddenly angry & $66.7 \%$ & $33.3 \%$ \\
8 & I sometimes feel like hurting other people & $31.7 \%$ & $68.3 \%$ \\
9 & I hate my life & $16.7 \%$ & $83.3 \%$ \\
10 & I don't like my privacy being disturbed & $100 \%$ & $0 \%$ \\
\hline
\end{tabular}

Section C looks at parenting styles that influence the emotions and attitudes of gifted students. Items 1 to 5 are Authoritarian parenting style characteristics, items 6 to 10 are Authoritarian parenting style characteristics, items 11 to 15 are Permissive parenting style characteristics, and items 16 to 20 are Neglect parenting style characteristics.

Table 03. Parenting Styles That Influence the Emotions and Attitudes

\begin{tabular}{clll}
\hline No & \multicolumn{1}{c}{ Items } & \multicolumn{1}{c}{ Yes } & \multicolumn{1}{c}{ No } \\
\hline 1 & I feel my future is determined by my parents & $30 \%$ & $70 \%$ \\
2 & I felt my life was framed and directed entirely by my parents & $21.7 \%$ & $78.3 \%$ \\
3 & There was no discussion or compromise in every ruling by my parents & $18.3 \%$ & $81.7 \%$ \\
4 & $\begin{array}{l}\text { I felt the rules and regulations by my parents were very strict and } \\
\text { oppressive of me }\end{array}$ & $16.7 \%$ & $83.3 \%$ \\
5 & I am punished/fined when I make a mistake & $43.3 \%$ & $56.7 \%$ \\
6 & My parents often ask me to talk about things & $68.3 \%$ & $31.7 \%$ \\
7 & My opinion is heard and appreciated & $70 \%$ & $30 \%$ \\
8 & Parents put conditions on me, but I understand the rationale to each & $76.7 \%$ & $23.3 \%$ \\
& condition set & & \\
9 & My parents were firm, but still supportive and encouraging in what I did & $88.3 \%$ & $11.7 \%$ \\
10 & I was given the freedom to do things, but was still given guidance and & $90 \%$ & $10 \%$ \\
& rationale by my parents & & \\
11 & My parents always supported all my actions & $63.3 \%$ & $36 \%$ \\
12 & My parents will fulfill what I want & $48.3 \%$ & $70 \%$ \\
13 & I don't feel stuck to getting what I want & $78.3 \%$ & $21.7 \%$ \\
14 & I have no problem communicating with my parents & $41.7 \%$ & $58.3 \%$ \\
15 & There has never been any conflict between me and my parents & $35 \%$ & $65 \%$ \\
16 & I am free to make every decision in life & $43.3 \%$ & $56.7 \%$ \\
17 & I am free to hang out with anyone I want & $11.7 \%$ & $88.3 \%$ \\
18 & My parents never took notice of me & $33.3 \%$ & $66.7 \%$ \\
19 & My parents were too unassuming when I felt like being heard & $15 \%$ & $85 \%$ \\
\hline 20 & I felt like I was not cared for by my parents & & \\
\hline
\end{tabular}

With the analysis according to the responses by the respondents, most answered Authoritative parenting style as the parenting style practiced in their respective family systems. So with Authoritative parenting style, able to show no dominant emotional and attitude problems among these intelligent students. The dominant emotional and attitude problems that the researchers tried to highlight, also showed a slight and almost insignificant percentage difference.

Adolescents are those who are still undergoing a comprehensive developmental process. As a parent, it is wise to choose a parenting style approach to suit the trends of today's teenagers. The acquisition of the overall findings of this study will be able to provide information that can be used as a basis for parents to be more focused in the process of educating children. This study is also expected to be a useful guide to departments or agencies such as the Ministry of Education Malaysia and the Ministry of Women, Family 
and Community Development in finding solutions to help raise awareness about the importance of parenting education.

\section{Conclusion}

As these youths are an important asset of the country, then they should be a priority in the effectiveness of education so that they become a very valuable national gem that is able to contribute energy and expertise to the country. It is hoped that with the existence of educational programs based on parenting education, hopefully give maximum impact on the development of emotions and positive attitudes among adolescents.

\section{Acknowledgment}

\section{References}

Amy, Loh Siew Mei (2000). Hubungan Antara Amalan Kekeluargaan Dengan Masalah Sosial Di Kalangan Pelajar Pusat Pengajian Sains Tulen USM, Pulau Pinang. Tidak diterbitkan. Tesis Sarjana Muda. Universiti Teknologi Malaysia, Skudai.

Azizi Yahaya dan Jaafar Sidek Latif (2006). Siri Kaunseling: Membentuk Identiti Remaja. (Cetakan Kedua). Bentong: PTS Professional Publishing Sdn. Bhd

Azizi Yahaya, Shahrin Hashim \& Mascilla Hamzah (2009). Masalah Salah Laku Agresif dalam Kalangan Pelajar Sekolah Rendah dan Hubungannya dengan Gaya Keibubapaan. Fakulti Pendidikan, Universiti Teknologi Malaysia, Johor.

Hamidah Sulaiman (2013). Hubungan Antara Kecerdasan Emosi Dengan Gaya Asuhan Ibu Bapa Dalam Kalangan Remaja Sekolah. Universiti Malaya.

Kimberly Kopko. 2007. Parenting Styles and Adolescents. Cornell Cooperative Extension.

Loeber, R. and Farrington, D. P. 2000. Young Children Who Commit Crime : Epidemiology, Developmental Origins, Risk Factors, Early Interventions, and Policy Implications. Development and Psychopathology. 12(4): 737-762

Mohd Majid Konting (1993). Kaedah Penyelidikan Pendidikan. Kuala Lumpur: Dewan Bahasa dan Pustaka.

Mustafa Hj. Daud (1997). Institusi Kekeluargaan Islam. (Cetakan Ketiga). Kuala Lumpur: Dewan Bahasa dan Pustaka

Noorzihan Mohamed Yin. 2004. Kenakalan Remaja dari Perspektif Islam dan Barat. Yayasan Dakwah Islamiah Malaysia, 26.06.2004. Retrieved on 10 Sept 2008, from http://www.yadim.com.my/Remaja/Remaja

Rosmah Dain. 2004. Personaliti anak - Keluarga kumpulan penting bentuk peribadi. Portal Pendidikan Utusan, 12.08.2004. Retrieved on 5 Sept 2008, from http://www.tutor.com.my

Samira Salimynezhad, Nahid Yusef Poor \& Asma Valizade. 2015. The Studies of Relationship between Parental Styles with Emotional Intelligence in Elementary Schools Students of MAKOO. 6th World conference on Psychology Counseling and Guidance, 14 - 16 May 2015

Zulkiple Ibrahim. 2007. Sikap kurang ajar anak: Ibu bapa patut dipersalahkan? mSTAR Online, 14.06.2007. Retrieved on 8 Aug 2008, from http://www.mstar.com.my

Z Mahmud, AR Habib \& S Amat (2001). Pendedahan Kendiri : Perkara Yang Diceritakan Oleh Remaja Kepada Ibu Bapa. Jurnal Pendidikan (UKM). 
The authors declare that they have no significant competing financial, professional or personal interests that might have influenced the performance or presentation of the work

Copyrights Holder: < paidin $><2021>$

https://doi.org/10.xxxx/xxxxx

Open Access Article | CC-BY Creative Commons Attribution 4.0 International License.

Word Count: Counseling

First Publication Right: BISMA The Journal of 